\title{
ASSESSING THE SUITABILITY OF MORPHOLOGICAL AND PHENOLOGICAL TRAITS TO SCREEN SESAME GENOTYPES FOR FUSARIUM WILT AND CHARCOAL ROT DISEASE RESISTANCE
}

\author{
Mohamed Abd El-Hamid Sayid El-Bramawy ${ }^{1 *}$ \\ Salah El-Sayed El-Hendawy', Waleed Ibrahim Amin Shaban ${ }^{2}$
}

\author{
${ }^{1}$ Agronomy Department, Faculty of Agriculture, Suez Canal University, 41522 Ismailia, Egypt \\ ${ }^{2}$ Agricultural Botany Department, Faculty of Agriculture \\ Suez Canal University, 41522 Ismailia, Egypt
}

Received: March 24, 2008

Accepted: August 13, 2008

\begin{abstract}
Since sesame genotypes differ significantly in many morphological and phenological traits, some of these traits could be suitable for direct selection among the sesame genotypes for Fusarium wilt and charcoal rot disease resistance. Forty-eight sesame genotypes that originated from different geographical regions were screened for their response to infection by Fusarium oxysporum $\mathrm{f}$. sp. sesami (FOS) and Macrophomina phaseolina (MPH), the Fusarium wilt and charcoal rot pathogens in 2005 and 2006 seasons, respectively. The seed yield and infection percentage by Fusarium wilt and charcoal rot pathogens were determined. Branch number and days to maturity as morphological traits and seed colour as phenological trait which represented the proposal for diversity among sesame genotypes were correlated with infection percentage and were used to examine the performance of these traits as screening criteria for Fusarium wilt and charcoal rot disease resistance. Our results showed that 57, 67 and $67 \%$ in 2005 and 77, 77 and $62 \%$ in 2006 of resistant genotypes for FOS, and 68,77 and $64 \%$ in 2005 and 80, 76 and $60 \%$ in 2006 of resistant genotypes for MPH had a medium branch number, and were of medium maturity and having creamy seed colour, respectively. According to the analysis of regression, branch number and seed colour were significantly correlated with infection percentages by FOS and/or MPH. Therefore, these traits may be used as indices for direct selection for resistance of sesame genotypes to Fusarium wilt and charcoal rot disease. However, no significant correlation was found between days to maturity and infection percentage by both fungi. Linear regression between infection percentage and three groups of branch number and seed colour indicated that the sesame genotypes had medium branch number and having creamy or white seed colour were the only covariant which significantly correlated with the infection percentage by FOS and/or MPH.
\end{abstract}

Key words: branch number, infection percentage, maturity days, vegetation, seed colour

*Corresponding address: el_bramawy71@hotmail.com 


\section{INTRODUCTION}

Sesame is an important oil crop in tropical and subtropical areas. The productivity in Egypt, however, remained virtually stagnant over recent decades because of its susceptibility to diseases such as wilt and charcoal rot caused by Fusarium oxysporum f. sp. sesami (FOS) and Macrophomina phaseolina (MPH), respectively. The FOS, is a soilborne, root pathogen colonizing xylem vessels and blocking them completely to effect wilting (Bateman et al. 1996). MPH infected at all growth stages plants, show a poor seedling establishment, and reduced vigor and productivity of older plants (Abawi and Corrales 1989). Most importantly, these pathogens may cause heavy yield losses in sesame ranging from 50 to $100 \%$, if management is not taken to control these pathogens (Gaber et al. 1998; Khaleifa 2003; El-Bramawy 2006; El-Shakhess and Khalifa 2007). Different management methods such as management of irrigation and fertilization regimes, and application of systemic fungicides have been recommended to reduce disease affects. They are very expensive, and non-friendly to environment, and usually only cause a temporary effect to overcome these pathogens (Stevenson 1983; Holley et al. 1985). In contrast, a complementary and a more permanent approach to minimizing the deleterious effects of these pathogens is to increase their resistance in current genotypes. The use of resistant genotypes is the most desirable control method because it provides a practical, long-term, and environmentally benign means of limiting the damage from these diseases (Wang et al. 2001). However, insufficient genetic knowledge of the resistance traits, lack of effective selection criteria and evaluation methods have all restricted progress to improve resistance in current sesame genotypes (El-Bramawy and Abdul Wahid 2006; Kavak and Boydak 2006).

In fact, there is a wide diversity in phenological and morphological traits, namely: number of branches and capsules, length of capsules and fruiting zone, date of maturity, and colour of seed and they all have been demonstrated among sesame genotypes (Li et al. 1991). The question that arises here is whether these criteria are reliable for screening sesame genotypes for wilt and charcoal rot pathogens?

Numerous studies have shown a relationship between some phenological and morphological traits and resistance to diseases. For instance, Dubin et al. (1998) and Mahto (2001) found that the resistance wheat genotypes to Helminthosporium leaf blight was associated with shorter plant height and late maturity. Most important, several reports have indicated that seed colour plays an important role in the resistance of plants to diseases. Statler (1970) reported that more total phenols in common bean plants cause greater resistance to root-rot disease. Harris and Burns (1973) have also mentioned that tannin conditioning seed colour is beneficial in the field due to its presence providing resistance to fungi. Li et al. (1991); Pastor-Corrales et al. (1998) and Islam et al. (2003) mentioned that the polyphenolics, of which tannins are a subset, are involved in seed colour expression and are often associated with plant resistance to pathogens or insects. From this point of view, some phenological and morphological traits could be valuable tools for screening and breeding a new germplasm for higher diseases resistance. The objective of our study was to evaluate the association of some phenological and morphological traits as simple, quick and economic screening criteria of resistance of 48 sesame genotypes to wilt and charcoal rot diseases. 


\section{MATERIALS AND METHODS}

\section{Plant materials}

Forty-eight genotypes of Sesamum indicum L. from different countries were used in this study. Ten genotypes were obtained from the Agriculture Research Centre, Giza, Egypt. Three genotypes, UN. A 130, GN. A 574 and KN. A 592 were obtained from the USA, Greece and north Korea, respectively. Fifteen promising lines were originated by hybridization and selection through a breeding program in the Experimental Farm of the Faculty of Agriculture at Suez Canal University. Twenty land races were collected from eight different agro-ecological zones which represented the proposed diversity distribution of sesame in Egypt. The names, origin, pedigree and diversity in phenological and morphological traits of 48 sesame germplasm are listed in table 1.

\section{Experimental design, inoculation of soil and agronomic practices}

A randomized complete block design with three replicates was used each season. In 2005 and 2006 growing seasons, sowing was done in wilt-sick and charcoal rot-sick plot in soil known to have a high inoculum density of both pathogenic fungi from a long-term sesame research field that was naturally infested with FOS and MPH, El-Bramawy (2006) and El-Bramawy and Abdul Wahid (2006).

To confirm infection of plants by FOS and MPH, plant segments excissed from infected stems and roots were surface sterilized and placed in Petri dishes containing saturated humid filter paper with sterilized water. The dishes were incubated for $72 \mathrm{~h}$ at $25^{\circ} \mathrm{C}$. Afterwards the plant segments were placed in Petri dishes containing sterilized PDA medium and incubated for $72 \mathrm{~h}$ at $25^{\circ} \mathrm{C}$. Colonies of pathogenic fungi that grew on the medium were identified as FOS and MPH based on the presence of morphological characteristics of each fungus according to Moubasher (1993). Reisolated pathogens weres compared with the original isolates to assure their identity.

Each entry was planted in a plot composed of two ridges $60 \mathrm{~cm}$ apart and $4 \mathrm{~m}$ in length $\left(4.8 \mathrm{~m}^{2}\right)$. The seeds were planted on the upper third of the ridge in hills with $10 \mathrm{~cm}$ between hills. The recommended field practices were carried out at a proper time as applied in the local area. The experimental soil was sandy textured $(94.5 \%$ sand, $2.5 \%$ silt and 3.0 clay). The $\mathrm{pH}$ value of soil was 7.8 .

\section{Measurements of infection percentage}

The percentages of diseased plants infected with wilt or charcoal rot pathogens were estimated according to specific disease symptoms for each fungus and recorded weekly throughout crop growth stages from 30 days after sowing till the end of the experiment. Infected by FOS plants were characterized by the internal vesicular discoloration and the appearance of plants wilting. The charcoal rot infection was expressed as root discoloration, black stem rot and pronounced reduction in root system of the infected plants (Smith and Carvil 1997).

\section{Scoring of germplasm for resistance}

Wilt and charcoal rot scores were measured using a 1-5 scale on twenty plants randomly selected from each plot. The germplasm that scored 1 - were considered resistant (R) (damage ranged from 0.1 to $20 \%$ ); 2 - as moderately resistant (MR) (dam- 


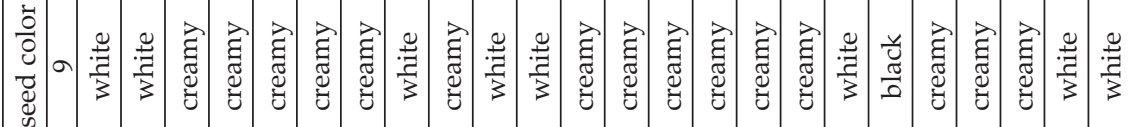

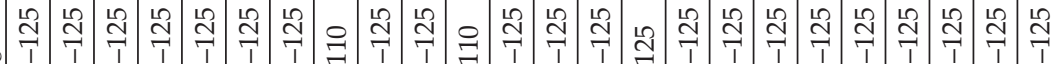

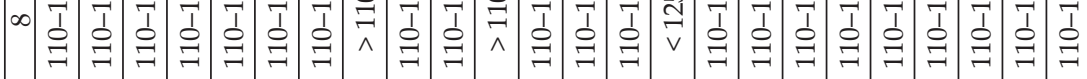

:

象

ฮี

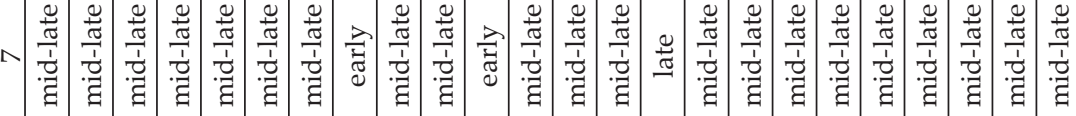

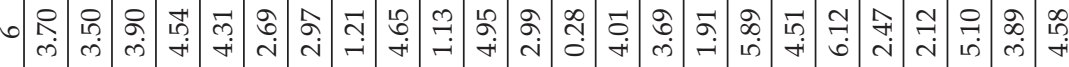

.

:

$\stackrel{\vartheta}{ \pm}$

$\Xi$

a

$\stackrel{\text { \& }}{2}$

:

ฮั

市

प्山

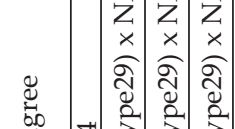

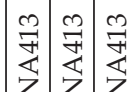

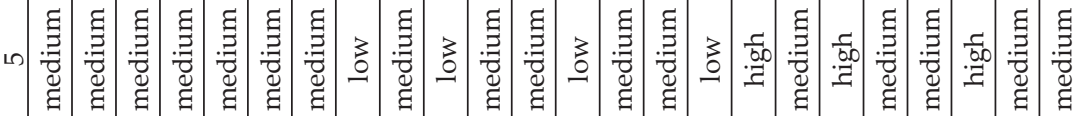

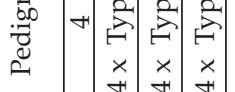

营

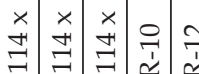

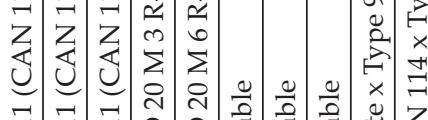

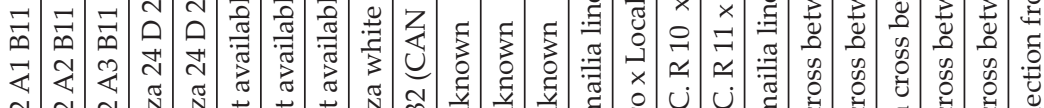

ลิ

$-\infty$

بـ

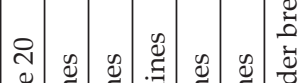

$:$

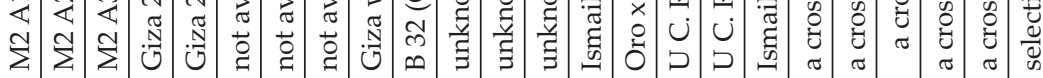

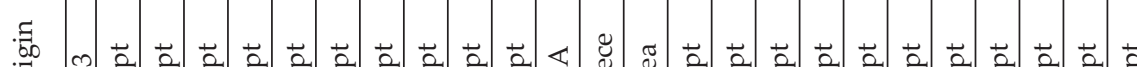

:

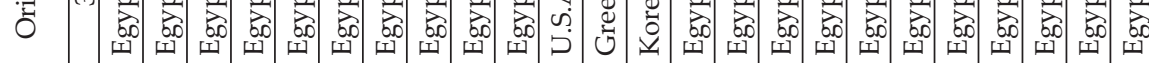

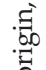

है?

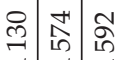

密

己

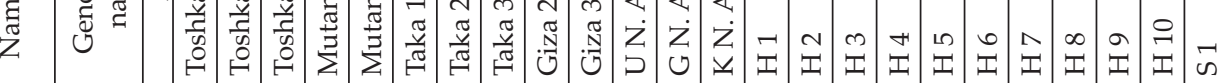

$\frac{\dot{a}}{\frac{\pi}{d}}$

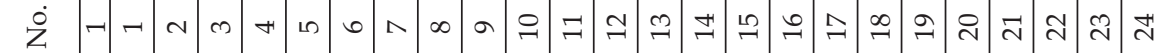




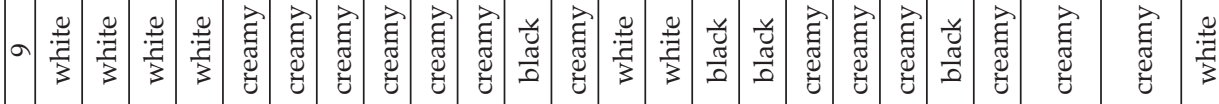

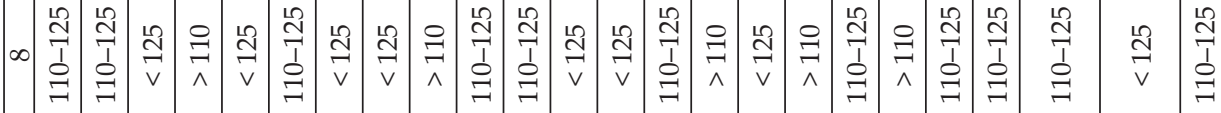

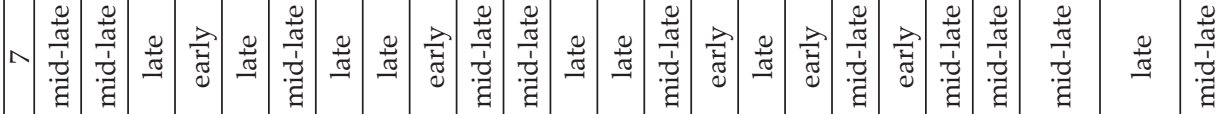

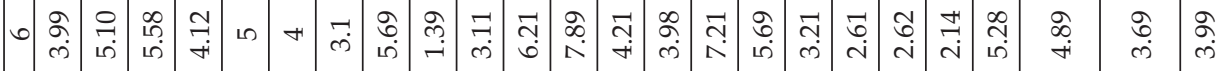

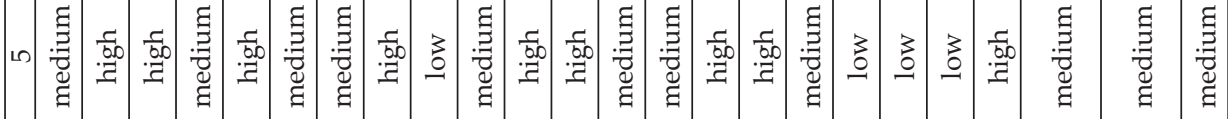

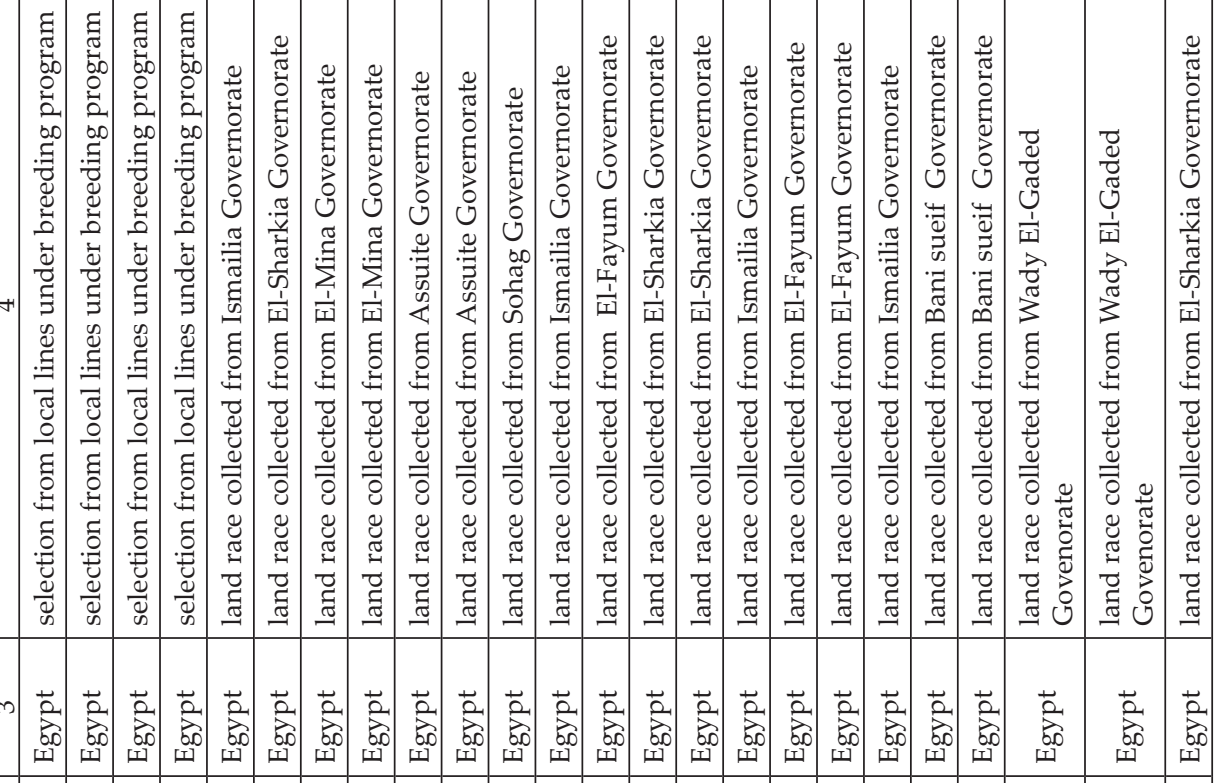

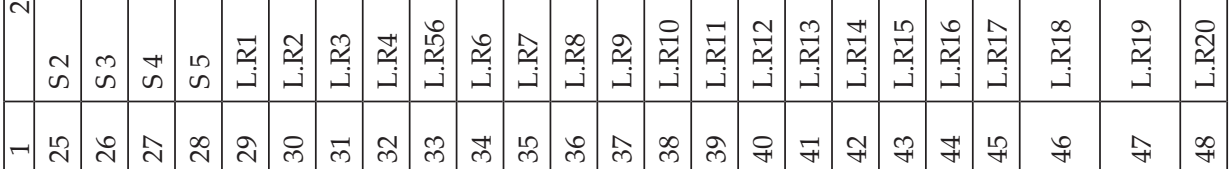


age ranged from 20.1 to $40 \%$ ); 3 - as moderately susceptible (MS) (damage ranged from 40.1 to $60 \%$ ); 4 - as susceptible (S) (damage ranged from 60.1 to $80 \%$ ), and 5 - as highly susceptible (HS) (damage ranged from 80.1 to 100\%) (Kavak and Boydak 2006). The wilted and rotted plants were counted and percentage of infected plants was calculated, then transformed to Arcsine values and prepared for statistical analysis.

\section{Phenolic and tannin analysis}

Total phenols were measured using the Folin Ciocalteu reagent method described by Dev Choudhury and Goswami (1983). Total tannins were determined colorimetrically as described in AOAC (1990). The amount of phenols and tannins are expressed in term of $\mathrm{mg} / \mathrm{g}$ dry seed.

\section{Statistical analysis}

Data were subjected to the analysis of variance using CoStat Version 6.311 (CoHort software, Berkeley, CA 94701). Treatment means were compared using Duncan's Multiple Range Test (Steel and Torrie 1980) of probability levels 0.05 or 0.01 . The relations between infection percentages by FOS and MPH, and branch number, days to maturity and seed colour were analyzed by regression analysis. The best equations to fit the relations were chosen by regression procedures with selection of forward, backward and stepwise methods. The relationship between infection percentages by FOS and $\mathrm{MPH}$, and three groups of branch number and seed colour were analyzed comparing the slops of linear regression using a covariance analysis (Antunez et al. 2001).

\section{RESULTS}

Highly significant variations were observed among evaluated genotypes in infection percentages and seed yield in conditions of plant infestation by Fusarium oxysporum f. sp. sesami (FOS) and Macrophomina phaseolina (MPH) (Table 2). The infection percentages by the pathogens varied among genotypes from 1.7 to $61.6 \%$ and from 2.2 to $53.4 \%$ in 2005 and from 1.4 to $54.2 \%$ and from 3.7 to $55.1 \%$ in 2006 . However, the seed yield ranged from 178.1 to $378.8 \mathrm{~kg} / \mathrm{Fed}\left(\mathrm{Fed}=4200 \mathrm{~m}^{2}\right)$ and from 181.5 to $392.1 \mathrm{~kg} /$ Fed in 2005, and from 160.0 to $383.2 \mathrm{~kg} /$ Fed and from 175.0 to $381.8 \mathrm{~kg} /$ Fed in 2006, respectively (Table 2).

The most tested genotypes fell in the scale as resistant $(\mathrm{R})$ and moderate resistant (MR). Averaged over two seasons, 49.0 and 38\% of infestation with F. oxysporum and 49.0 and $44 \%$ of infestation with M. phaseolina fell in the scale as R and MR, respectively. Only 13 and 7\% of tested genotypes (averaged over two seasons in conditions of infestation with FOS and MPH, respectively) were grouped in the scale as MS.

Interestingly, 57, 67 and $67 \%$ in 2005 and 77, 77 and $62 \%$ in 2006 of resistant genotypes for FOS and 68, 77 and 64\% in 2005 and 80, 76 and 60\% in 2006 of resistant genotypes for $\mathrm{MPH}$ had a medium branch number, and were of medium maturity and having creamy seed colour, respectively. However, 29, 19 and 10\% in 2005 and 8,12 and $8 \%$ in 2006 of resistant genotypes to FOS and 23, 9 and 5\% in 2005 and 12, 12 and $0 \%$ in 2006 of resistant genotypes to $\mathrm{MPH}$ had a high branch number, were of early maturity and having black seed colour, respectively. 


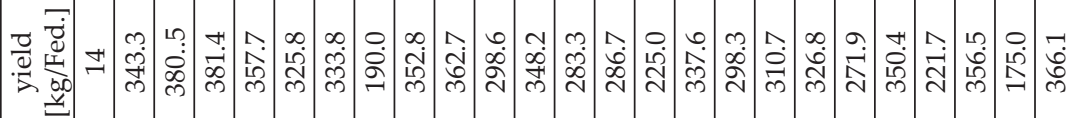

究

苛

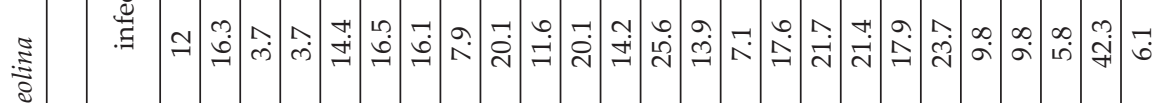

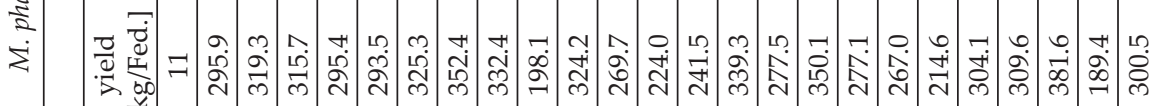

完

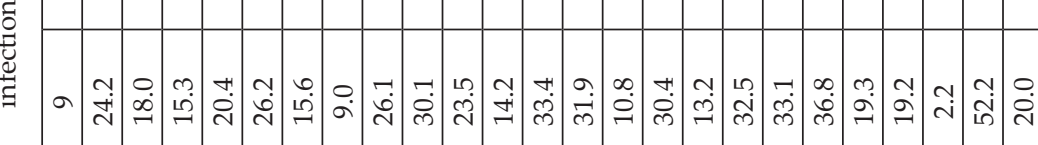

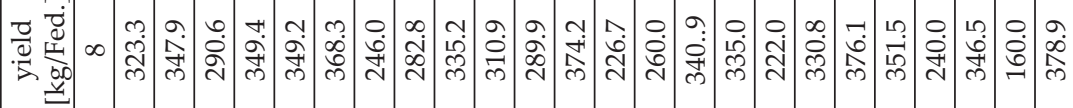

ఫे

:

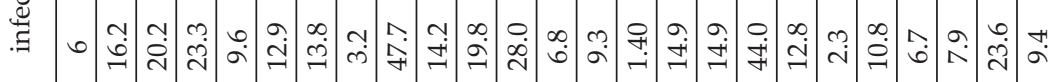

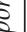

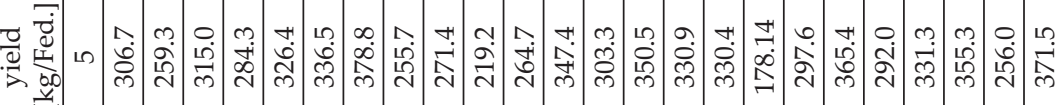

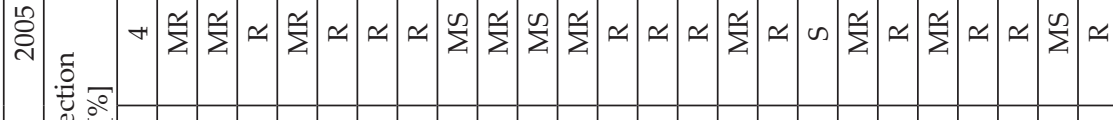

导

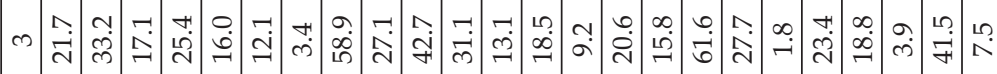

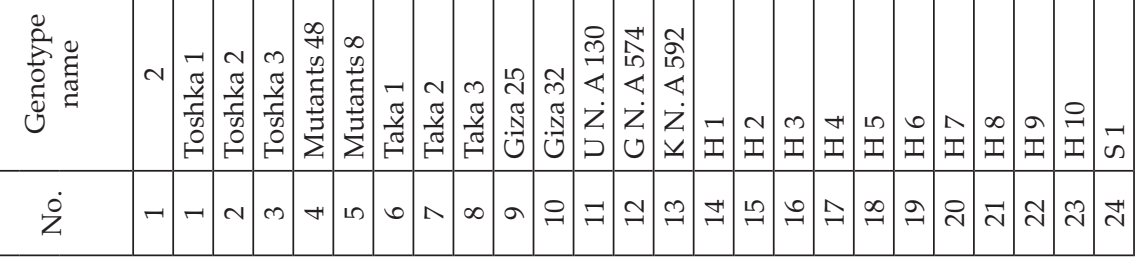




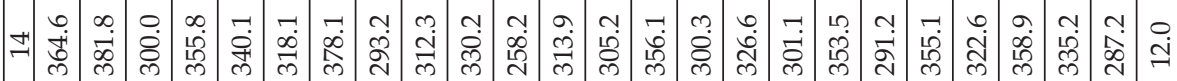

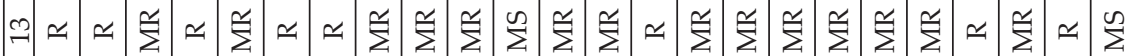

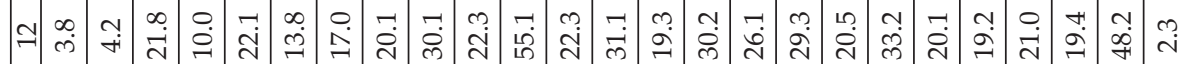

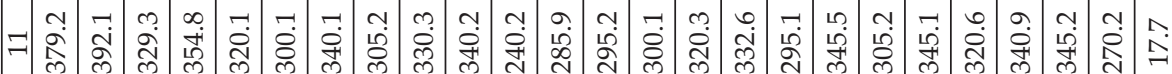

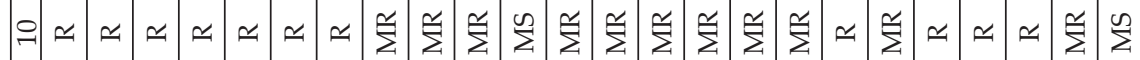

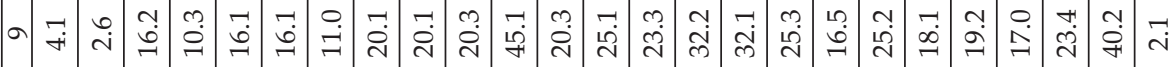

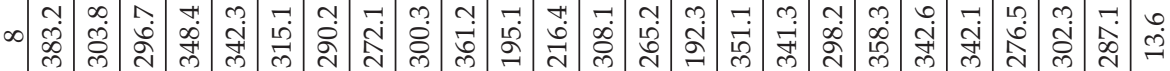

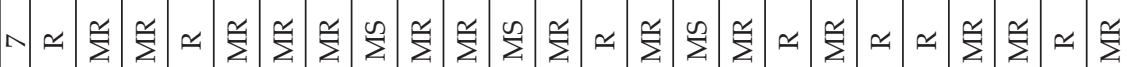

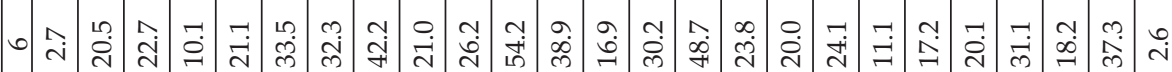

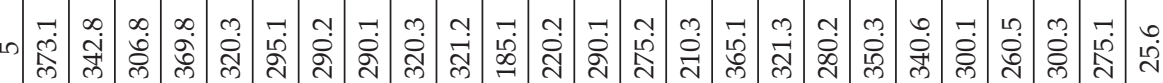

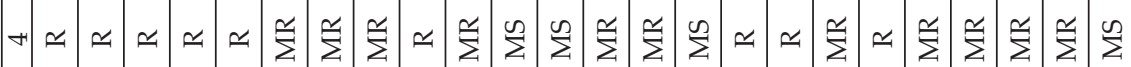

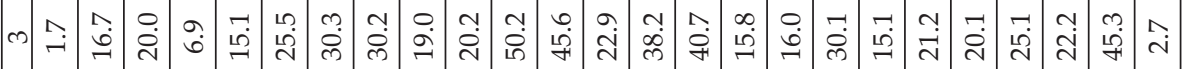

$\frac{\frac{0}{2}}{\frac{\pi}{2}}$ 
The predictive and reliable branch number, days to maturity and seed colour as screening criteria for resistance to wilt and charcoal rot diseases among were accepted for sesame genotype evaluation, the relationships between these variables and infection percentage were analyzed (Table 3 ). If the coefficient of determination $\left(\mathrm{R}^{2}\right)$ is significant, these variables could be useful criteria for evaluation of sesame genotypes to wilt and/or charcoal rot diseases. A quadratic regression equation based on stepwise analysis best fits the relationship. In general, both branch number and seed colour were significantly correlated with the infection percentages by FOS. Seed colour was the only variable which significantly correlated with the infection percentage by MPH. However, days to maturity were not significantly correlated with disease incidence (Table 3).

Table 3. Regression equations and correlation coefficients between infection percentage by F. oxysporum f. sp. sesami and M. phaseolina (Y), and branch number, days to maturity and seed colour (X) in 2005 and 2006

\begin{tabular}{|c|c|c|c|c|}
\hline \multirow{3}{*}{ Variables } & \multicolumn{4}{|c|}{ Infection percentage } \\
\hline & \multicolumn{2}{|l|}{2005} & \multicolumn{2}{|l|}{2006} \\
\hline & regression equation & $\mathrm{R}^{2}$ & regression equation & $\mathrm{R}^{2}$ \\
\hline \multicolumn{5}{|c|}{ F. oxysporum f. sp. sesami } \\
\hline Branch number & $Y=37.8-9.5 X+1.33 X^{2}$ & $0.12^{*}$ & $Y=21.0-5.0 X+1.1 X^{2}$ & $0.27^{* *}$ \\
\hline Days to maturity & $Y=526.3-8.4 X+0.04 X^{2}$ & $0.01^{\mathrm{ns}}$ & $Y=692.9-11.4 X+0.05 X^{2}$ & $0.04^{\text {ns }}$ \\
\hline Seed color & $Y=53.8-35.5 X+9.4 X^{2}$ & $0.20^{* *}$ & $Y=39.2-29.0 X+9.0 X^{2}$ & $0.20^{* *}$ \\
\hline \multicolumn{5}{|c|}{ M. phaseolina } \\
\hline Branch number & $Y=35.2-7.2 X+0.9 X^{2}$ & $0.07^{\mathrm{ns}}$ & $Y=20.8-3.1 X+0.6 X^{2}$ & $0.06^{\mathrm{ns}}$ \\
\hline Days to maturity & $Y=499.5-8.1 X+0.04 X^{2}$ & $0.02^{\mathrm{ns}}$ & $\mathrm{Y}=269.1-4.1 \mathrm{X}+0.02 \mathrm{X}^{2}$ & $0.01^{\mathrm{ns}}$ \\
\hline Seed color & $Y=34.4-17.8 X+5.5 X^{2}$ & $0.18^{*}$ & $Y=22.2-10.8 X+4.2 X^{2}$ & $0.14^{*}$ \\
\hline
\end{tabular}

$\mathrm{ns},{ }^{*},{ }^{* *}$ not significant, and significant at the 0.05 and 0.01 probability levels, respectively

A linear regression, through a covariance analysis, was used in studying the relationship between the infection percentages by both pathogens, and the branch number and seed colour. In this relationship, the infection percentages were considered as dependent variables, with the branch number and seed colour as independent variables.

For branch number, all genotypes were classified into three groups, low, medium and high branch numbers; and the infection percentage by Fusarium vs. three groups of branch number were fitted and the equations obtained were:

$$
\begin{aligned}
& Y=26.8-\underset{(\mathrm{t}=-1.98)^{0.03}}{7.8 X_{1}}-\underset{(\mathrm{t}=0.37)^{0.71}}{2.6 X_{2}} \\
& Y=28.9-\underset{(t=-3.00)^{0.04}}{11.9 X_{1}}-\underset{(t=-1.9)^{0.06}}{10.3 X_{2}}
\end{aligned}
$$

where $Y, X_{1}$ and $X_{2}$ are, respectively, the infection percentage, medium branch and low branch numbers. 
The infection percentages of charcoal rot vs. three groups of branch number were fitted and the equations obtained were:

$$
\begin{aligned}
& Y=23.0-\underset{(t=-0.21)^{0.84}}{0.9 X_{1}}+\underset{(t=0.52)^{0.61}}{3.0 X_{2}} \\
& Y=22.7-\underset{(t=-1.7)^{0.10}}{6.3 X_{(t=0.41)^{0 . \theta 1}}} 2.1 X_{(}
\end{aligned}
$$

where $Y, X_{1}$ and $X_{2}$ are, respectively, the infection percentage, medium branch and low branch number.

The results of above equations indicate that when the relationship between the groups of branch number and infection percentages were analyzed simultaneously (Equations 1-4), the sesame genotypes having medium branch number were the only covariate which significantly correlated with the infection percentage by FOS, and had the lower infection by 7.8 and $11.9 \%$ than genotypes having high branch number, in 2005 and 2006, respectively (Equations 1 and 2).

For seed colour, all genotypes were also classified into three groups, creamy, white and black seed colour; and the infection percentages of Fusarium wilt vs. three groups of seed colour were fitted and the equations obtained were:

$$
\begin{aligned}
& Y=31.6-\underset{(t=-1.98)^{0.05}}{11.3 X_{1}}-\underset{(t=-0.62)^{0.54}}{3.9 X_{2}} \\
& Y=33.2-\underset{(t=-3.30)^{0.02}}{16.0 X_{1}}-\underset{(t=-2.7)^{0.01}}{14.0 X_{2}}
\end{aligned}
$$

where $Y, X_{1}$ and $X_{2}$ are the infection percentages, creamy seed and white seed colour, respectively.

The infection percentages of charcoal rot vs. three groups of seed colour were fitted and the equations obtained were:

$$
\begin{aligned}
& Y=31.0-\underset{(t=-2.01)^{0.05}}{9.9 X_{1}}-\underset{(t=-1.66)^{0.10}}{8.8 X_{2}} \\
& Y=28.1-\underset{(t=-2.37)^{0.02}}{10.5 X_{1}}-\underset{(t=-2.62)^{0.01}}{12.4 X_{2}}
\end{aligned}
$$

where $Y, X_{1}$ and $X_{2}$ are the infection percentages, creamy seed and white seed colour, respectively.

The results of above equations (Equations 5-8) indicate that the sesame genotypes having creamy and white seed colour were the covariates which significantly correlated with the infection percentage by FOS and MPH and less with infection by 11.3 and $3.9 \%$ in 2005, and by 16.0 and 14.0 in 2006 for Fusarium wilt disease incidence, and by 9.9 and $8.8 \%$ in 2005, and by 10.5 and $12.4 \%$ in 2006 for charcoal rot disease incidence compared with genotypes having black seed colour, respectively.

\section{DISCUSSION}

Since field study of plant reaction to the pathogen is difficult, laborious and time consuming, breeders often search for easily and rapidly evaluated traits that are correlated with resistance. Results of this study indicated that due to a significant relationship between branch number and seed colour, and infection percentage by 
Fusarium oxysporum f. sp. sesami (FOS) and/or Macrophomina phaseolina (MPH) (Table 3), branch number and seed colour might be suitable traits for direct selection among the sesame genotypes for resistance to these diseases.

Wu et al. (2000) reported that selection for branch number may be significant in the development of Amaranthus resistant to root rot disease. Furthermore, Lee and Choi (1986) reported that the germplasm resources of sesame could be classified based on branch number and this trait is controlled by one gene (nb) (Brar and Ahuja 1979). These findings indicate that the trait of branch number may be possibly used as screening criterion, if it was associated with the infection percentage caused by fungal pathogens. Our results showed that branch number was significantly correlated with the infection percentage by FOS, but not with the infection percentage by MPH (Table 3). This result may be due to fact that the fungus of Fusarium wilt penetrates sesame plant roots and spreads up into the stem through the water conducting vessels which causes plants to wilt from the top down or branch by branch and causes plant vessels plugged and damaged. Our results also showed that the sesame genotypes having medium or low branch number had a lower infection by FOS by 7.8 and $2.6 \%$ in 2005 and 11.9 and $10.3 \%$ in 2006 than did genotypes with high branch numbers, respectively (Equations 1 and 2). This may be due to a high branch number causing good favourable conditions for the spread of pathogens. Furthermore, as infection spreads, the water feeding system becomes blocked, therefore the water uptake is not in agreement with the water transpiration and the plants become more susceptible to the pathogen and this increases symptom expression.

The results of our study showed that the Fusarium wilt or charcoal rot incidence were not correlated with days to maturity (Table 3). These results suggest that the days to maturity were not a suitable trait for direct selection among the sesame genotypes for resistance to these diseases. These results may be due to the fact that, the plants get infected by both pathogens at any stage of crop development. In this regard, Songa et al. (1997) found that time to maturity did not seem to influence or affect the susceptibility or resistance to MPH of various bean accessions.

Our results also indicate that the sesame genotypes having creamy and white seed colour were generally more resistant to Fusarium wilt and charcoal rot diseases than genotypes having black seed colour. These results were confirmed by the linear regression, and a covariance analysis, considering the infection percentages by (FOS) and $\mathrm{MPH}$, and the three groups of seed colour (equations 5-8). The increase of resistance of genotypes having creamy and white seed colour infested with both fungal pathogens may be due to the increase concentration of total phenols and tannins in their seeds. The concentration of total phenols and tannins in genotypes with creamy, white and black seed colour were in average of about 122.0, 77.7 and $74.0 \mathrm{mg}$ per $100 \mathrm{~g}$ dry seed for total phenols, and 143.0, 72.7 and $70.0 \mathrm{mg}$ per $100 \mathrm{~g}$ dry seed for total tannins, respectively (data not shown). The findings obtained in this study were in good agreement with those reported by Islam et al. (2003), who found that polyphenolics, of which tannins are a subset, are involved in seed colour expression and are often associated with plant resistance to pathogens or insects. Statlar (1970) also reported that the more total phenols in common bean plants caused a greater resistance to root-rot disease. Harris and Burns (1973) mentioned tannin as beneficial in the field due to its presence providing resistance to fungi and seed viviparty. El-Fiki et al. (2004) indicated that the amounts of total phenols were obviously higher in the sesame entries that were classified as highly resistant and resistant than did those classified as sus- 
ceptible and highly susceptible. Li et al. (1991) found in 2992 accessions of sesame that the most resistant of sesame genotypes to MPH had white seed colour, while black or grey-seeded genotypes tended to be susceptible, and yellow or brown-seeded ones intermediate. Our and previous results may indicate that the seed colour trait could successfully be used to predict the resistance of sesame genotypes to fusarium wilt and charcoal rot diseases without conducting tedious crop experiments. In addition, we suggest that this desirable phenological trait could be transfered to high-yielding cultivars by using conventional hybridization, biotechnological and bridge techniques for the introgression of wilt and charcoal rot diseases resistance genes.

\section{CONCLUSION}

Regarding phenological and morphological traits as screening criteria for resistance to Fusarium wilt and charcoal rot diseases in sesame genotypes, it can be concluded that the branch number and seed colour traits may successfully be used to predict the resistance of sesame genotypes to F. oxysporum and M. phaseolina without conducting tedious crop experiments.

\section{ACKNOWLEDGMENTS}

We thank Dr. Khaled M. Yousef and Mr. Ahmed Raian for providing possibility of chemical analysis.

\section{REFERENCES}

AOAC., 1990. Official Methods of Analysis. Association of Official Analytical Chemists. 15th ed., K. Helrich (ed.), Arlington, VA.

Abawi G.S., Corrales P. 1989. Charcoal rot screening procedure and virulence of Macrophomina phaseolina isolates on dry edible bean. Turrialba 39: 200-207.

Antunez I., Retamosa E.C., Villar R. 2001. Relative growth rate in phylogenetically related deciduous and evergreen woody species. Oecolo 128: 172-180.

Brar G.S., Ahuja K.L. 1979. Sesame, its culture, genetics breeding and biochemistry. Annu. Rev. Plant Sci. 1: 245-313.

Bateman G.L., Kwaśna H., Ward E. 1996. Relationship among Fusarium spp. estimated by comparing restriction fragment length polymorphism in polymerase chain reaction amplified nuclear DNA. Can. J. Microbiol. 42: 1232-1240.

Dev Choudhury M.N., Goswami M.R., 1983. A raped method for determination of total polyphenolic matters in tea (Camellia sinensis L.). Two Bud 30: 59-61.

Dubin H.J., Arun B., Begum S.N., Bhatta M., Dhari R., Goel L.B., Joshi A.K., Khanna B.M., Malaker P.K., Pokhrel D.R., Rahman M..M., Saha N.K., Shaheed M.A., Sharma R.C., Singh A.K., Singh R.M., Singh R.V., Vargas M., Verma P.C. 1998. Results of the South Asia regional Helminthosporium leaf blight and yield experiments. p. 1993-94. In: "Helminthosporium Blights of Wheat: Spot Blotch" (E. Duveiller, H.J. Dubin, J. Reeves, A., McNab, eds.).

El-Bramawy M.A. S. 2006. Inheritance of resistance to Fusarium wilt in some crosses under field conditions. Plant Prot. Sci. 42 (2): 99-105.

El-Bramawy M.A.S., Abdul Wahid O.A. 2006. Field resistance of sesame (Sesamum indicum L.) crosssources to charcoal root rot disease caused by Macrophomina phaseolina (Tassi.) Goid. Plant Prot. Sci. 42 (2): 66-73. 
El-Fiki A.I., El-Deeb F., Mohamed F.G., Khalifa M.M.A. 2004. Controlling sesame charcoal rot incidence by Macrophomina phaseolina under field conditions by using the resistant cultivars and some seed and soil treatments. Egypt J. Phytoph. 32 (1-2): 103-118.

El-Shakhess S.A.M., Khalifa M.M.A. 2007. Compining ability and heterosis for yield, yield components, charcoal-rot and Fusarium wilt diseases in sesame. Egypt J. Plant Breed. 11 (1): 351-371.

Gaber M.R., Hussein N.A., Saleh O.I., Khalil M.A. 1998. Susceptibility of certain varieties and genotypes and control of wilt and root rot diseases of sesame attributed to Fusarium oxysporum $\mathrm{f}$. $\mathrm{pp}$ sesami and Macrophomina phaseolina. Egypt. J. Microb. 33 (3): 403-428.

Harris H.B., Burns R.E. 1973. Relationship between tannin content of sorghum grain and preharvest seed molding. Agron. J. 65: 957-959.

Holley J.D., Hall R., Hofstra G. 1985. Effects of cultivar resistance, leaf wetness duration and temperature on rate of development of potato early blight. Can. J. Plant Sci. 65: 179-184.

Islam F.M.A., Rengifo J., Redden R.J., Basford K.E., Beebe S.E. 2003. Association between seed coat polyphenolics (tannins) and disease resistance in common bean. Plant Foods Human Nutr. 58: 285-297.

Khaleifa M.M. A. 2003. Pathological studies on charcoal rot disease of sesame. Ph.D. Thesis. Argon. Dep. Fac. of Agric., Moshtohor, Zagazig Univ., Benha, branch, Egypt,. 295 pp.

Kavak H., Boydak E. 2006. Screeing of the risistance levels of 26 sesame breeding lines of Fusarium wilt disease. Plant Pathol. J. 5:157-160.

Lee C.H., Choi K.Y. 1986. Genetic studies on quantities characters for sesame breeding (in Korean, English Abstr.) Korean J. Breed. 18: 242-248.

Li 1.1., Wang S.Y., Fang X.P., Hung Z.H., Wang S.T., Li M.L., Cui M.Q. 1991. Identification of Macrophmina phaseolina resistant germoplasm of sesame in China. Oil crops of China 1 (3-6): 23.

Mahto B.N. 2001. Effect of helminthosporium leaf blight on yield components and determination of resistance in selected wheat varieties. Ann. Agric. Res. 22: 177-181.

Moubasher A.H. 1993. Soil Fungi in Qatar and Other Arab Countries. The Scientific and Applied Research Center, Univ. of Qatar, 566 pp.

Pastor-Corrales M.A., Jara C., Singh S.P. 1998. Pathogenic variation in sources of and breeding for resistance to Phaeoisariopsis griseola causing angular leaf spot in common bean. Euph. 103: 161171.

Smith G.S., Carvil O.N. 1997. Field screening of commercial and experimental soybean cultivars for their reaction to Macrophomina phaseolina. Plant Dis. 81:363-368.

Songa W., Hillocks R.J., Mwangombe A.W., Buruchara R., Ronno W.K. 1997. Screening common bean accessions for resistance to charcoal rot (Macrophomina phaseolina) in eastern Kenya. Exp. Agric. 33: 459-468.

Statler G.D. 1970. Resistance of bean plants to Fusarium solani f.sp. phaseoli. Plant Dis. Rep 54: 698699.

Steel R.G.D., Torrie J.H. 1980. Principles and Procedures of Statistics 2nd ed. McGraw-Hill, New York.

Stevenson W.R. 1983. Evaluation of fungicides for control of potato early blight 1982. In: Fungicide and nematicide test results of 1982. Am. Phytopat. Soc. 38.

Wang M., Farnham M.W., Thomas C.E. 2001. Inheritance of true leaf stage downy mildew resistance in broccoli. J. Amer. Soc. Hort. Sci. 126 (6): 727-729.

Wu H., Sun M., Yue S., Sun H., Cai1 Y., Huang R., Brenner D., Corke H. 2000. Field evaluation of an Amaranthus genetic resource collection in China. Gene. Resou. and Crop Evol. 47: 43-53. 


\section{POLISH SUMMARY}

\section{OKREŚLANIE PRZYDATNOŚCI CECH MORFOLOGICZNYCH I FENOLOGICZNYCH DO ATESTACJI ODPORNOŚCI GENOTYPÓW SEZAMU NA WIĘDNIĘCIE FUZARYJNE ORAZ ZGNILIZNĘ WYWOŁANA PRZEZ MACROPHOMINA PHASEOLINA}

Ponieważ genotypy sezamu znacznie różnią się pod względem cech morfologicznych i fenologicznych, niektóre z tych cech mogłyby być przydatne do bezpośredniej selekcji genotypów na odporność przeciw więdnięciu fuzaryjnemu i zgniliźnie wywołanej przez Macrophomina phaseolina. W latach 2005 i 2006 prowadzono atestację 48 genotypów sezamu pochodzących z różnych rejonów geograficznych, uwzględniając reakcję na porażenie przez Fusarium oxysporum f. sp. sesami (FOS) oraz Macrophomina phaseolina (MPH). Określano plon nasion i procent porażenia przez te patogeny. Liczba rozgałęzień roślin oraz liczba dni do osiągnięcia dojrzałości były badanymi cechami morfologicznymi, a barwa nasion stanowiła badaną cechę fenologiczną. Cechy te były skorelowane z procentem porażenia i stanowiły kryterium atestacji. Uzyskane wyniki wykazały, że odpowiednio w latach 2005 i 2006 - 57, 67 i 67\% oraz 77, 77 i 62\% genotypów sezamu odpornych na Fusarium, a także 68, 77 i 64\% oraz 80, 76 i $60 \%$ genotypów odpornych na M. phaseolina miało średnią liczbę rozgałęzień i średni termin dojrzewania, i również kremową barwę nasion. Zgodnie z analizą regresji, liczba rozgałęzień i barwa nasion były istotnie skorelowane z procentem porażenia przez Fusarium i/lub M. phaseolina. Więc cechy te mogą być wykorzystane jako wskaźniki do bezpośredniej selekcji genotypów na odporność przeciw obu chorobom. Jednak nie stwierdzono istotnej korelacji między ilością dni do osiągnięcia dojrzałości i procentem porażenia przez obydwa te patogeny. Liniowa regresja pomiędzy procentem porażenia i trzema grzybami liczby rozgałęzień oraz barwą nasion wykazała, że genotypy sezamu mające średnią liczbę rozgałęzień i kremową lub biała barwę nasion stanowiły jedyną kowariancję, która była istotnie skorelowana z procentem porażenia przez Fusarium i/lub M. phaseolina. 